\title{
STRATEGI PjBL BERBANTUAN MODUL 6M MENINGKATKAN SIKAP SISWA DALAM MENDUKUNG PROGRAM SEKOLAH ADIWIYATA
}

\author{
Ferawati $^{1}$, Maya Ekaningtias ${ }^{2}$ \\ Program Studi Pendidikan Biologi, STKIP Bima. Jalan Piere Tendean Kel. Mande Tel. Fax (0374) \\ 42801, Bima 84191, Indonesia \\ 1,2 Dosen Program Studi Pendidikan Biologi STKIP BIMA. \\ Email:Ferawati0505@gmail.com ${ }^{1} \underline{2}$
}

\begin{abstract}
Abstrak
Melalui penerapan strategi project based learning (PjBL) berbantuan modul pengelolaan sampah berbasis $6 M$ penelitian ini bertujuan untuk meningkatkan sikap siswa dalam pengelolaan sampah. Penelitian merupakan Penelitian Tindakan Kelas yang dilakukan dalam dua siklus terdiri atas empat tahapan: perencanaan, pelaksanaan, observasi dan refleksi pada kelas VIII SMP Negeri 4 kota Bima. Hasil penelitian menunjukkan bahwa peningkatan sikap siswa siklus 1 sebesar 32,9\% rerata pretes 65,1; postes 76,1 Gain Score 0,3 tergolong sedang. Sedangkan siklus II peningkatan sikap siswa sebesar 10,7\% dengan rerata pretes 68,7 posttes 78,9, Gain Score 0,3 tergolong sedang.
\end{abstract}

Kata Kunci: Project Based Learning (PjBL), Modul 6M, Sikap.

\section{PENDAHULUAN}

Persoalan sampah seakan tidak pernah berhenti. Paradigma sampah sebagai barang yang tidak berguna dan harus dibuang sampai saat ini masih melekat dalam masyarakat. Saat ini Indonesia merupakan negara kedua setelah Tiongkok penghasil sampah plastik terbesar didunia, penerapan plastik berbayar yang diterapkan oleh pemerintah ternyata tidak mampu merubah perilaku masyarakat dalam mengurangi penggunaan sampah. Kota Bima dalam keberadaannya tidak terlepas dari permasalahan sampah, kesadaran masyarakat yang masih sangat kurang akan kebersihan lingkungan, manajemen pengelolaan sampah yang dilakukan selama ini hanya menggunakan metode kumpul-angkut-buang, masyarakat sepenuhnya masih beranggapan bahwa pemerintah yang memiliki tanggung jawab penuh dalam pengelolaan sampah. Padahal sampah merupakan salah satu faktor penyebab terjadinya bencana banjir yang kerap terjadi beberapa tahun terakhir.

Pendidikan lingkungan dibutuhkan dan harus diberikan kepada anak sejak dini agar mereka mengerti dan memiliki kesadaran penuh akan lingkungan. Al Muhdhar (1998) menyatakan bahwa diperlukan beberapa strategi antara lain pembudayaan tentang lingkungan sejak dini untuk menciptakan konsistensi antara pengetahuan dan sikap, terhadap perilaku masyarakat. Salah satu cara mewujudkan perilaku positif terhadap pengelolaan sampah yakni dengan mengembangkan program pendidikan lingkungan hidup yaitu melalui pendidikan lingkungan disekolah. Sekolah merupakan tempat memperoleh segala ilmu pengetahuan 
dan berbagai norma, serta etika yang dapat menjadi dasar manusia menuju terciptanya kesejahteraan hidup dalam menuju cita-cita pembangunan berkelanjutan. Sebagai generasi penerus, sikap siswa terhadap lingkungan sangat penting karena secara langsung akan memainkan peranan dalam memberikan solusi untuk masa depan lingkungan kita. Selain ditujukan kepada peserta didik, program pengolahan sampah dapat juga ditujukan kepada orang dewasa yaitu guru dan anggota keluarga (Jurczak, et al. 2003 dalam Setyowati, 2011).

Hasil observasi yang dilakukan tentang kondisi yang ada di SMP Negeri 4 Kota Bima bahwa kesadaran warga sekolah akan kebersihan lingkungan masih sangat kurang dalam menuju sekolah Adiwiyata, pendidikan tentang lingkungan yang masih kurang, siswa sepenuhnya memberikan tanggung jawab penuh kepada petugas kebersihan sekolah untuk membersihkan lingkungan sekolah, sehingga lingkungan sekolah terlihat bersih hanya ketika dipagi hari, namun apabila sudah jam istrahat banyak terlihat sampah berserakan karena masih warga sekolah yang membuang sampah secara sembarangan, ketersediaan tempat sampah masih kurang, tempat pengelolaan sampah yang sama sekali tidak ada, dan sekolah kurang memiliki alat-alat kebersihan secara baik. Kegiatan pembelajaran tentang sampah yang dilakukan oleh guru IPA yang mengajar pada kelas VIII selama ini masih berpusat guru, dimana siswa hanya pasif mendengarkan dan menerima pengetahuan dari guru. Dominasi guru dalam proses pembelajaran menyebabkan siswa lebih banyak menunggu sajian dari guru dari pada mencari dan menemukan sendiri pengetahuan, keterampilan serta sikap siswa tentang pengolahan sampah.

Budaya kurang peduli terhadap sampah merupakan pola perilaku yang memprihatinkan dan membutuhkan strategi solusi pemecahan. Konsep 6M yaitu mengurangi, menggunakan kembali, mengganti, memisahkan, mendaur ulang, dan mengomposkan dipandang tepat digunakan sebagai bekal menangani masalah perilaku kurang peduli terhadap sampah. Pemanfaatan modul pengelolaan sampah berbasis $6 \mathrm{M}$ sudah diterapkan beberapa lingkungan sekolah di Kota Malang. Modul ini memiliki manfaat besar bagi siswa, guru, dan sekolah secara langsung dan bagi pemerintah secara tidak langsung. Bagi siswa, guru, dan sekolah modul ini terdiri atas modul guru dan modul siswa. Kedua modul tersebut akan menyediakan informasi secara detil operasional tentang model pembelajaran pengelolaan sampah berbasis 6M. Modul disusun berdasarkan kriteria pengembangan modul yang baik, sehingga memudahkan bagi guru maupun siswa dalam melaksanakan pembelajaran 
pengelolaan sampah baik teoritik maupun praktik (Al Muhdhar dkk., 2013).

Ada beberapa hal yang mendasari mengapa Project Based Learning (PjBL) diterapkan yaitu selama ini pembelajaran masih berpusat pada guru sehingga siswa tidak terbiasa melihat alternatif lain yang mungkin dapat dipakai dalam menyelesaikan suatu masalah secara efektif dan efesien. Siswa akhirnya hanya menghafal saja semua konsep atau rumus tanpa memahami maknanya dan tidak mampu menerapkannya dalam berbagai situasi adaptif. Kreatifitas pembelajaran tidak hanya berpusat pada guru, akan tetapi sudah waktunya siswa diberi kesempatan untuk mengembangkan sendiri pengetahuannya tanpa menghilangkan peran guru sebagai fasilitator dan klarifikator (Porworeni, 2004). Penerapan pembelajaran berbasis konstruktivistik dalam hal ini project based learning (PjBL) pada mata pelajaran biologi merupakan upaya pembinaan kesadaran terhadap manfaat lingkungan hidup. Melalui pembelajaran konstruktivistik dalam hal ini penerapan projecr based learning (PjBL) pada materi ekosistem, siswa mengkonstruk pengetahuan tentang lingkungan hidup sehingga dari kegiatan pembelajaran siswa merasa memiliki dan mencintai lingkungannya dan dapat membentuk sikap dan perilaku positif terhadap lingkungan (Mahannal, 2009).
Berdasarkan pandangan dari identifikasi masalah di atas perlu diupayakan penerapan strategi project based learning (PjBL) berbantuan modul pengolahan sampah berbasis $6 \mathrm{M}$ terhadap peningkatan sikap siswa dalam menumbuhkan kesadaran peduli lingkungan di SMP Negeri 4 Kota Bima.

\section{METODE}

Penelitian ini termasuk Penelitian Tindakan Kelas dengan menerapkan strategi project based learning (PjBL) berbantuan modul pengelolaan sampah berbasis $6 \mathrm{M}$. Pelaksanaannya menggunakan dua siklus, yang terdiri atas: perencanaan, pelaksanaan, observasi, dan refleksi. Subjek penelitian yaitu siswa kelas VIII A, D, dan E SMPN 4 Kota Bima yang jumlah 74 siswa. Hasil tindakan di setiap siklus selanjutnya dianalisis menggunakan rumus Gain Score ternormalisasi. Tingkat perolehan Gain Score ternormalisasi dikategorikan ke dalam tiga kategori, yaitu: g - tinggi jika $(<\mathrm{g}>)>0,7$; g sedang jika $0,7 \geq(<\mathrm{g}>) \geq 0,3$; dan $\mathrm{g}-$ rendah jika $(<\mathrm{g}>)<0,3$. Hake (1998).

Teknik pengambilan data aspek sikap menggunakan tes sikap skala Likert di tiap siklusnya yang dilakukan di awal, tengah, dan akhir tindakan, serta lembar kampanye poster. 


\section{HASIL DAN PEMBAHASAN}

Hasil penelitian berupa penilaian sikap siswa dalam pengelolaan sampah berbasis 6M menggunakan Gain Score ternormalisasi siklus I tertera pada Tabel 1 menunjukkan bahwa sikap siswa siklus I rerata pretes sebesar $65,1 \%$, postes $76,1 \%$, mengalami peningkatan sebesar $32,9 \%$ dengan Gain Score 0,3 tergolong sedang. Sedangkan siklus II rata-rata pretes $68,7 \%$, posttes $78,9 \%$ mengalami peningkatan meningkat 10,17\% dengan Gain Score 0,3 tergolong sedang.
Hasil penilaian pengamatan kampanye poster menunjukkan rata-rata kelas VIII A sebesar 84\%, VIII D sebesar $81 \%$, dan kelas VIII E sebesar $81 \%$. Aspek semangat tergolong tinggi dengan rata-rata skor 21,17 sedangkan kekompakan tergolong rendah dengan rata-rata skor 19,33 bahwa rata-rata skor keseluruhan sebesar $82 \%$ yang artinya bahwa pelaksanaan kegiatan kampanye poster dapat dikategorikan baik seperti tertera pada Tabel 2.

Tabel 1. Rerata pretes dan postes siklus I dan siklus II sikap siswa SMPN 4 Kota Bima

\begin{tabular}{cccccc}
\hline \multicolumn{3}{c}{ Rerata Tes Sikap } & \multicolumn{3}{c}{ Rata-rata Tes Sikap } \\
\hline Pretes & Postes & Gain Score & Pretes & Postes & Gain Score \\
\hline 65,1 & 76,1 & $\mathbf{0 , 3}$ & 68,7 & 78,9 & $\mathbf{0 , 3}$ \\
\hline
\end{tabular}

Tabel 2. Hasil rata-rata Nilai Kampanye Poster I Siswa kelas VIII SMPN 4 Kota Bima

\begin{tabular}{lcccc}
\hline \multirow{2}{*}{ Aspek yang dinilai } & \multicolumn{3}{c}{ Kelas } & Rata-rata \\
\cline { 2 - 5 } & VIII A & VIII D & VIII E \\
\hline Keberanian & 20 & 18 & 20 & 19.33 \\
\hline Kekompakan & 21 & 22 & 20 & 21 \\
\hline Kemampuan mempengaruhi orang lain & 20 & 20 & 20 & 20 \\
\hline Semangat & 23 & 21 & 21 & 21.66 \\
\hline \multicolumn{1}{c}{ Rata-rata } & 84 & 81 & 81 & $\mathbf{8 2}$ \\
\hline
\end{tabular}

Berdasarkan hasil penelitian dapat $65,1 \%$, dan postest sebesar 76.1 gain score 0,3 dijelaskan bahwa rata-rata nilai pretes dan kategori sedang. Sedangkan pada siklus II postes sikap siswa SMPN 4 Kota Bima diperoleh nilai pretest sebesar $68.7 \%$ dan menunjukkan adanya peningkatan sikap siswa postest sebesar $78.9 \%$ peningkatan sebesar sebelum dan sesudah penerapan pembelajaran $10.17 \%$ dengan gain score 0.3 Ini berarti dengan strategi Project Based Learning bahwa kenaikan sikap siswa setelah penerapan (PjBL) berbantuan modul pengelolaan sampah berbasis $6 \mathrm{M}$. Hasil peningkatan sikap siswa siklus I sebesar $32.9 \%$ dengan rerata pretest strategi Project Based Learning (PjBL) berbantuan modul pengelolaan sampah berbasis $6 \mathrm{M}$ tergolong sedang. Kondisi 
tersebut menunjukkan bahwa penerapan strategi Project Based Learning (PjBL) berbantuan modul pengelolaan sampah berbasis $6 \mathrm{M}$ efektif meningkatkan sikap siswa dalam mendukung sekolah menuju sekolah Adiwiyata.

Kampanye poster yang dilakukan siswa siklus I meliputi kampanye poster tentang upaya pengendalian dampak sampah, Penilaian kampanye poster yang dilakukan meliputi empat aspek, yaitu aspek keberanian, aspek kekompakan, aspek kemampuan mempengaruhi orang lain, dan aspek semangat. Rata-rata hasil penilaian keseluruhan aspek kampanye poster siklus I tentang upaya pengendalian dampak sampah diperoleh nilai $82 \%$ tergolong tinggi, yang artinya bahwa sikap siswa dalam mengkampanyekan poster pembudayaan $6 \mathrm{M}$ dikategorikan baik.

Hasil penilaian produk daurulang sampah siswa selama kegiatan daurulang sampah meliputi penilaian aspek perencanaan bahan, aspek proses pembuatan, dan aspek hasil produk. Penilaian produk daurulang sampah siklus I nilai terendah diperoleh pada aspek perencanaan bahan, dan aspek produk berupa inovasi diperoleh nilai $81,4 \%$, yang artinya bahwa dalam membuat produk daurulang sampah perencanaan bahan dan inovasi tergolong baik. Sedangkan nilai tertinggi diperoleh pada aspek persiapan alat dan bahan diperoleh nilai $86 \%$, yang artinya bahwa dalam membuat produk daurulang sampah tergolong baik. Rata-rata keseluruhan aspek pada penilaian produk daurulang sampah sebesar $82,3 \%$, yang artinya sikap siswa selama pembuatan produk daurulang sampah tergolong tinggi.

Berdasarkan hasil temuan diatas dapat dijelaskan bahwa hasil penelitian ini menunjukkan adanya peningkatan sikap siswa setelah menerapkan strategi Project Based Learning (PjBL) berbantuan modul pengelolaan sampah berbasis 6M. Temuan yang mendukung penelitian ini ialah penelitian Ferawati (2014) tentang penerapan strategi project based learning (PjBL) berbantuan modul pengelolaan sampah berbasis $6 \mathrm{M}$ dapat meningkatkan sikap siswa dalam mendukung program sekolah adiwiyata.

Sikap muncul dari berbagai bentuk pilihan, sikap dikembangkan dalam tiga modal, yaitu: afeksi, kecenderungan perilaku dan kognisi. Respon afektif adalah respon fisiologis yang mengekspresikan kesukaan individu terhadap sesuatu. Kecenderungan perilaku adalah indikasi verbal dari maksud seorang individu. Respon koghnitif adalah pengevaluasian secara koghnitif terhadap sesuatu obyek sikap. Kebanyakan sikap individu adalah hasil belajar sosial dari lingkungannya. Jika dikaitkan dengan penelitian ini bahwa dalam penelitian ini 
bahwa dalam pembelajaran berbasis proyek peserta didik dilatih untuk dapat mengembangkan sikapnya baik afeksi, kognisi maupun konasi dengan tujuan agar siswa memiliki respon afeksi yang baik terhadap lingkungan.

Sikap positif terhadap lingkungan melalui strategi Project Based Learning (PjBL) juga terbentuk akibat nilai sosial yang ada dalam strategi Project Based Learning (PjBL). Dalam Project Based Learning (PjBL) terdapat nilai kooperatif sehingga siswa terbiasa berinteraksi dengan rekan sekelompok untuk menyusun berbagai rancangan aktifitas yang berkaitan dengan materi yang diajarkan. Kegiatan diskusi membuka peluang terjadinya interaksi di mana mendiskusikan apa yang mereka ketahui dan siswa diarahkan untuk saling bertukar pikiran.

Uraian diatas didukung oleh Rahmawati (2017) bahwa strategi Project Based Learning (PjBL) berbantuan modul pengelolaan sampah berbasis $6 \mathrm{M}$ mampu meningkatkan sikap dan perilaku siswa dalam pengelolaan sampah. Mahannal dkk. (2009) bahwa pembelajaran lingkungan hidup berbasis proyek memiliki pengaruh terhadap perkembangan sikap siswa. Hal senada juga dikemukakan oleh Wahyudin (1998 dalam Mahannal, 2009) bahwa jalur pendidikan merupakan usaha untuk mencapai terwujudnya masyarakat yang memiliki sikap dan perilaku berwawasan lingkungan. Bukti- bukti lain yang mendukung penelitian ini yaitu (Wibowo dalam Darmawan, 2009) bahwa strategi PjBL dapat mempengaruhi sikap siswa terhadap ekosistem sungai. Selain itu Tesser (2003 dalam Darmawan, 2009) menjelaskan bahwa sikap dapat mengalami perubahan akibat pengalaman, suatu metode pembelajaran mampu mengakibatkan perubahan sikap dalam hal strategi Project Based Learning (PjBL), strategi ini mampu meningkatkan sikap siswa terhadap lingkungan hidup karena awalnya menanamkan konsep yang benar dan maksimal untuk mengembangkan fisik siswa. Sekolah sebagai lingkungan belajar mempunyai peranan penting terhadap pemberdayaan sikap. Melalui proses belajar terjadi komunikasi dan transfer pengetahuan nilai. Dengan demikian sikap terletak pada proses kognisi dalam belajar. Berdasarkan uraian diatas maka dapat disimpulkan bahwa penerapan strategi Project Based Learning (PjBL) berbantuan modul pengelolaan sampah berbasis $6 \mathrm{M}$ dapat meningkatkan sikap siswa di SMPN 4 Kota Bima.

\section{KESIMPULAN}

Berdasarkan paparan data dan temuan penelitian serta pembahasan, dapat diambil kesimpulan bahwa Penerapan strategi Project Based Learning (PjBL) berbantuan modul pengelolaan sampah berbasis $6 \mathrm{M}$ di kelas VIII 
A, VIII D, dan VIII E SMPN 4 Kota Bima tahun pelajaran 2017/2018 dapat meningkatkan sikap siswa dalam mendukung program sekolah Adiwiyata. Penerapan strategi Project Based Learning (PjBL) berbantuan modul pengelolaan sampah berbasis $6 \mathrm{M}$ ini memiliki keunggulan dalam meningkatkan sikap siswa, pada proses siswa diberikan kesempatan untuk mengeksplorasi kecakapan baik kecakapan akademis, kecakapan sosial, kecakapan proses maupun kecakapan sosial dengan menumbuhkan rasa percaya diri, sikap toleransi, bekerja sama, dan saling menghargai pendapat.

\section{DAFTAR PUSTAKA}

Al Muhdhar, M.H.I. (1998). Keterkaitan antara Faktor Sosial, Faktor Ekonomi, Faktor Budaya, Pengetahuan, dan Sikap Ibu-ibu Rumah Tangga dalam Pengelolaan Sampah Rumah Tangga, dan Manifestasi Perilaku Ibu-ibu Rumah Tangga dalam Pengelolaan Sampah Rumah Tangga di Kota madia Surabaya. Disertasi tidak diterbitkan. Malang: Program Pascasarjana Universitas Negeri Malang.

Al Muhdhar, M.H.I, dkk. (2013). Modul Pengelolaan Sampah Berbasis 6M Modul Pendukung untuk Sekolah Adiwiyata. Direncanakan diterbitkan. Malang. Universitas Negeri Malang.

Ferawati. (2014). Penerapan Strategi Project Based Learning Berbantuan Modul Pengelolaan Sampah Berbasis $6 M$ dalam Menuju Sekolah Adiwiyata di
SMPN 15 Kota Malang. Tesis tidak diterbitkan. Malang: Program Pascasarjana Universitas Negeri Malang.

Hake, R.R. (1998). Interactive-Engagement vs Traditional Methods: a six-thousandstudent Survey of Mechanics Test Data for Introductory Physics Courses.American Journal of Physics. $66(1)$.

Kemmis, S dan R. Mc Taggart. (1998). The Action Research Planner. Victoria: Deakin University.

Mahannal, Susriyati, dkk. (2009). Pengaruh Pembelajaran Project Based Learning (PjBL)pada Materi Ekosistem terhadap Sikap dan Hasil Belajar Siswa SMAN 2 Malang. Malang: Jurnal Universitas Negeri Malang.

Rahmawati, F. (2017). Penerapan Strategi PjBL Berbantuan Modul 6M Meningkatkan Sikap dan Perilaku Siswa Dalam Pengelolaan Sampah. JIME, Vol. 3. No. 1.

Setiowati, E. (2011). Pengembangan Modul Multimedia Pengelolaan Sampah Berwawasan Sains Teknologi Masyarakat sebagai Upaya Peningkatan Pengetahuan, Sikap, dan Perilaku Peserta Didik SMA. Disertasi tidak diterbitkan. Malang: Program Pascasarjana Universitas Negeri Malang.

Walgito, B. (2003). Psikologi Sosial (Suatu Pengantar). Yogyakarta: Andi

Wiweko, S. (2008). Sekolah Adiwiyata Sekolah Peduli dan Berbudaya Lingkungan. Makalah disajikan dalam Sosialisasi Sekolah Adiwiyata. 